\title{
You and Planned Giving
}

\section{Robert J-P. Hauck, APSA}

You may be contemplating giving for the first time to APSA's Centennial Campaign or to such worthy APSA programs as the Congressional Fellowship Program, the Ralph Bunche Summer Institute, or the Minority Identification Project, or you may be puzzling over how you might add to what you have already given. The tax consequences of a gift are rarely the principal reason for making a charitable gift, but maximizing the tax benefits of a gift to APSA certainly makes sense.

One question you need to consider is the timing of your gift. Charitable gifts made during your lifetime are probably the most effective form of giving because they produce both immediate income tax deductions

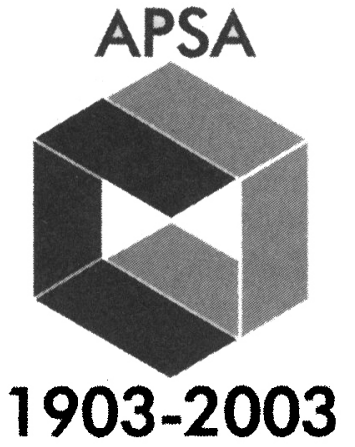
and reduce estate taxes after your death. You may prefer, in addition, to defer your gift. Testamentary giving, or deferred giving in the form of bequests and life insurance policies, produce significant estate tax benefits.

Testamentary giving has already had a profound impact on the Association's programs. Four of APSA's awards are funded through charitable bequests. The Kammerer, Bunche, and Humphrey Awards are funded by a $\$ 25,000$ bequest honoring Gladys $\mathrm{M}$. Kammerer in the will of William Kammerer. The 1972 Kammerer endowment benefited from strong stock markets and has grown to approximately $\$ 140,000$. In 1984 , the estate of John Gaus bequeathed approximately $\$ 32,000$ to APSA to encourage scholarship in public administration. The gift made the John Gaus Distinguished Lectureship and Award possible. Since 1984, the Gaus endowment has almost doubled under the management of the APSA's Trust and Development Committee.

As you consider deferred giving, bear the following in mind.

\section{Bequests}

Including APSA in your will is a relatively simple undertaking that will benefit future generations of political scientists. Though it is best to consult your attorney about precise language when preparing or revising your will, the following bequest language suggests what you might include if you wish to make an unrestricted bequest to APSA:

I give [a specified dollar amount] or [the rest, residue, and remainder of my estate] to the American Political Science Association, a nonprofit, educational organization in Washington, DC.

If you wish to make a restricted bequest to APSA, language like the following may suffice:

I give [a specified dollar amount] or [the rest, residue, and remainder of my estate] to the American Political Science Association, a nonprofit, educational organization in Washington, DC, for the benefit of [name of specific program, e.g., The Congressional Fellowship Program].
When specifying the purpose of your restricted bequest, it is best to be as general as possible because specific needs and program names do change over time. APSA will be glad to consult with you and your advisors if you would like information about bequests or APSA programs you might wish to support. If you do include APSA in your will, please inform APSA of your intended gift. Your generosity will be recognized in $P S$.

\section{Giving a Life Insurance Policy}

If, as a result of your estate planning, you find that you no longer need a life insurance policy that you purchased, naming APSA as the owner and beneficiary of your life insurance policy allows you to receive a tax deduction equal to the cash surrender value of the policy (if the policy is paid in full) or the premium payments made each year. To receive the tax benefit, you must name the Association your insurance policy's irrevocable owner and beneficiary.

The gift of an insurance policy is an excellent way to make a sizeable deferred gift. To transfer ownership of a life insurance policy to the Association:

1. Contact your insurer and tell them that you wish to make APSA the irrevocable owner and beneficiary of your policy. Your insurance broker will need the Association's address and telephone number.

2. Send a separate letter to APSA informing the Association of your gift so that you may be appropriately recognized. 